\title{
SLOVENSKA SLOVNICA
}

Toporišič, Jože

$\mathbf{P}$ razširjena izdaja edine znanstvene slovnice slovenskega jezika Slovenska slovnica avtorja dr. Jožeta Toporišiča. Prva izdaja je izšla leta 1976, druga, pregledana in razširjena izdaja s poglavji o sporočanju, zgodovinskem razvoju slovenskega knjižnega jezika ter njegovih nerešenih vprašanjih leta 1984 , tretja, nespremenjena izdaja leta 1991, četrta izdaja z letnico 2000 pa prinaša številne dopolnitve in novosti.

Slovnica obravnava vsa jezikovna področja, zajeta v devet poglavij: Zvrstnost slovenskega jezika, Glasoslovje, Besedoslovje, Besedotvorje, Oblikoslovje, Skladnja, Sporočanje, Slovenski jezik v času in Sodobna vprašanja knjižnega jezika in jezikoslovja.

V poglavju Zvrstnost slovenskega jezika je avtor deloma razširil in besedilno ponazaril le socialne zvrsti.

V poglavju Glasoslovje so novost razvrstitev naglašenih kračin, mesto naglasa in kakovost samoglasnikov, usklajena s Slovarjem slovenskega knjižnega jezika, pisanje širokih samoglasnikov pa s Slovenskim pravopisom 1 Pravila iz leta 1990 , podrobneje pa so pojasnjeni tudi vizualni posnetki slušne ravnine in dopolnjeni podnapisi k posameznim slikam.

Poglavje Besediloslovje ima kar nekaj novosti: podrobneje so razčlenjeni besedna naglasnost in pisna razsežnost besedja ter besedna druženja na podlagi pomena: so- in protipomenke, nad-in podpomenke, enakozvočnice (novosti so so prikazane tudi grafično $-\mathrm{z}$ grafi in tabelami, slovarski del pa vključuje tudi besedne zveze).

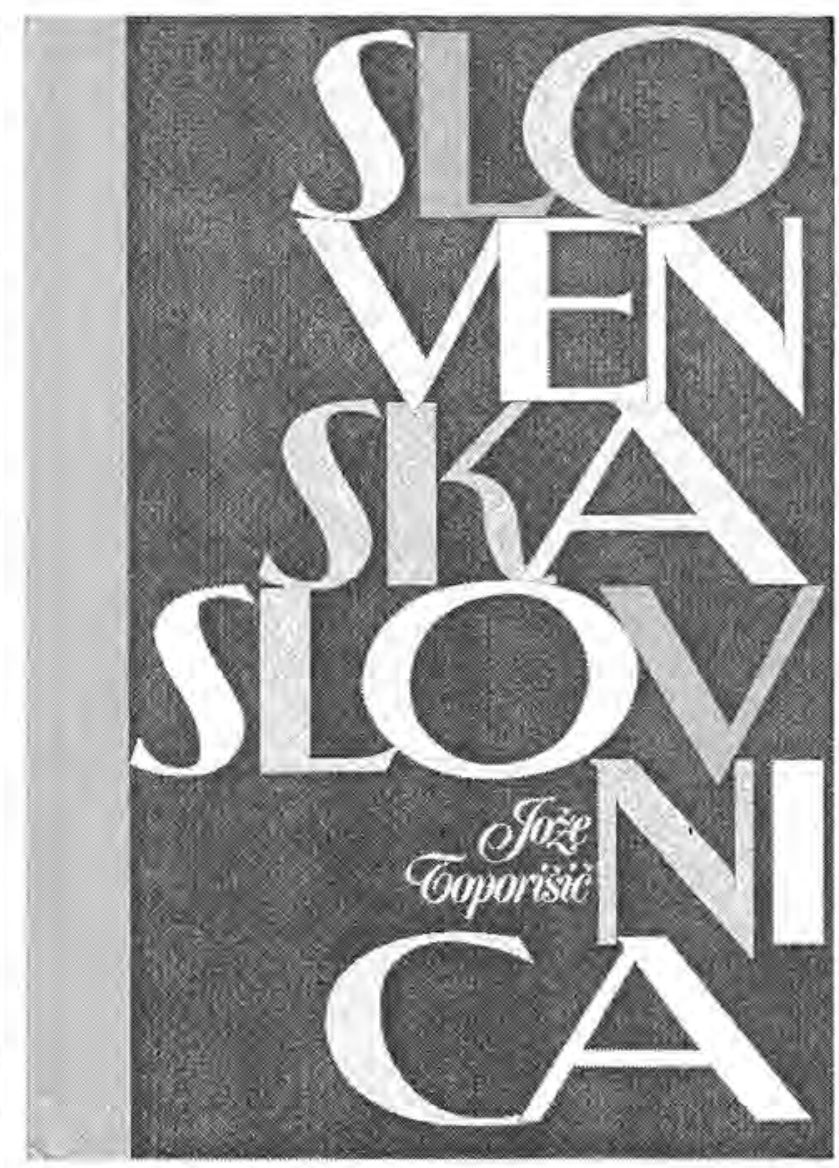

V poglavju Besedotvorje je precej dopolnjen oblikoglasni del, teorija enot po besedotvornih vrstah pa na podlagi novejših raziskav o besedotvornem algoritmu. Nekoliko je dopolnjen tudi del o naglasnosti tyorjenk.

Poglavje Oblikoslovje je usklajeno s prozodijsko normo kolikosti po Slovarju slovenskega knjižnega jezika (prejšnje tri izdaje so se namreč pri tem opirale - sicer $\mathrm{z}$ novega teoretičnega vidika - na Slovenski pravopis iz leta 
1962), pri členkih pa je v primerjavi $\mathrm{z}$ izdajo iz leta 1984 dodana še ena klasifikacija.

V poglavju Skladnja je avtor razširil podpoglavji o upovedovanju in besednih zvezah, dopolnil pa je tudi podpoglavje o besedilni skladnji.

$\mathrm{V}$ poglavju Sporočanje je treba opozoriti predvsem na teoretično usmerjeno zajetje pragmatike, s poudarkom na teoriji govornih dejanj. Nekateri segmenti pragmatike pa so deloma upoštevani že v poglavju Skladnja.

Zadnji dve poglavji Jezik v času ter Sodobna vprašanja slovenskega knjižnega jezika in jezikoslovja pa sta v primerjavi z izdajo iz leta 1984 bolj ali manj nespremenjeni.

Vidimo, da sta še največ sprememb doživeli poglavji o skladnji in sporočanju, poudariti pa moramo, da je avtor tudi zelo razširil obseg bibliografskega dela, tako da je bibliografija 4. izdaje verjetno največja zbirka jezikoslovnih bibliografskih enot doslej.

Ker smo zadnjo izdajo Slovenske slovnice na policah knjigarn pogrešali že od leta 1997, je vsekakor razveseljivo, da je pred nami nova izdaja, dopolnjena in razširjena $\mathrm{z}$ novejšimi dognanji univerzitetnikov in raziskovalcev na Inštitutu za slovenski jezik SAZU. Zlasti za učitelje in profesorje slovenskega jezika, študente slovenskega jezika, lektorje bo še naprej nepogrešljiv pripomoček pri njihovem delu.

Marija Sonja Pezdirc 